Chlorination of drinking water has eradicated most waterborne disease epidemics. However, small water-supply systems struggle to maintain water quality and aging water-distribution systems are prone to contamination. By the year 2025, California's projected population of 48 million will demand between 1 trillion and 5 trillion gallons per year. Municipal demands clearly will exceed the currently available supply of tap water, forcing conservation and reuse. Future regulations are expected to focus on the quality of the water flowing from the user's tap, rather than the quality exiting the water-treatment facility. As little as $16 \%$ of the water treated and conforming to drinking-water health standards is likely to come into direct contact with humans, such as for bathing and drinking. Development of dual water-distribution systems would separate water destined for human consumption from that destined for firefighting, toilet flushing and other domestic uses. As industry manufactures new compounds for drugs, antibiotics, household products and so on, water treatment must be modified to remove or neutralize these new contaminants. Monitoring for new and chlorine-resistant pathogens is also needed.

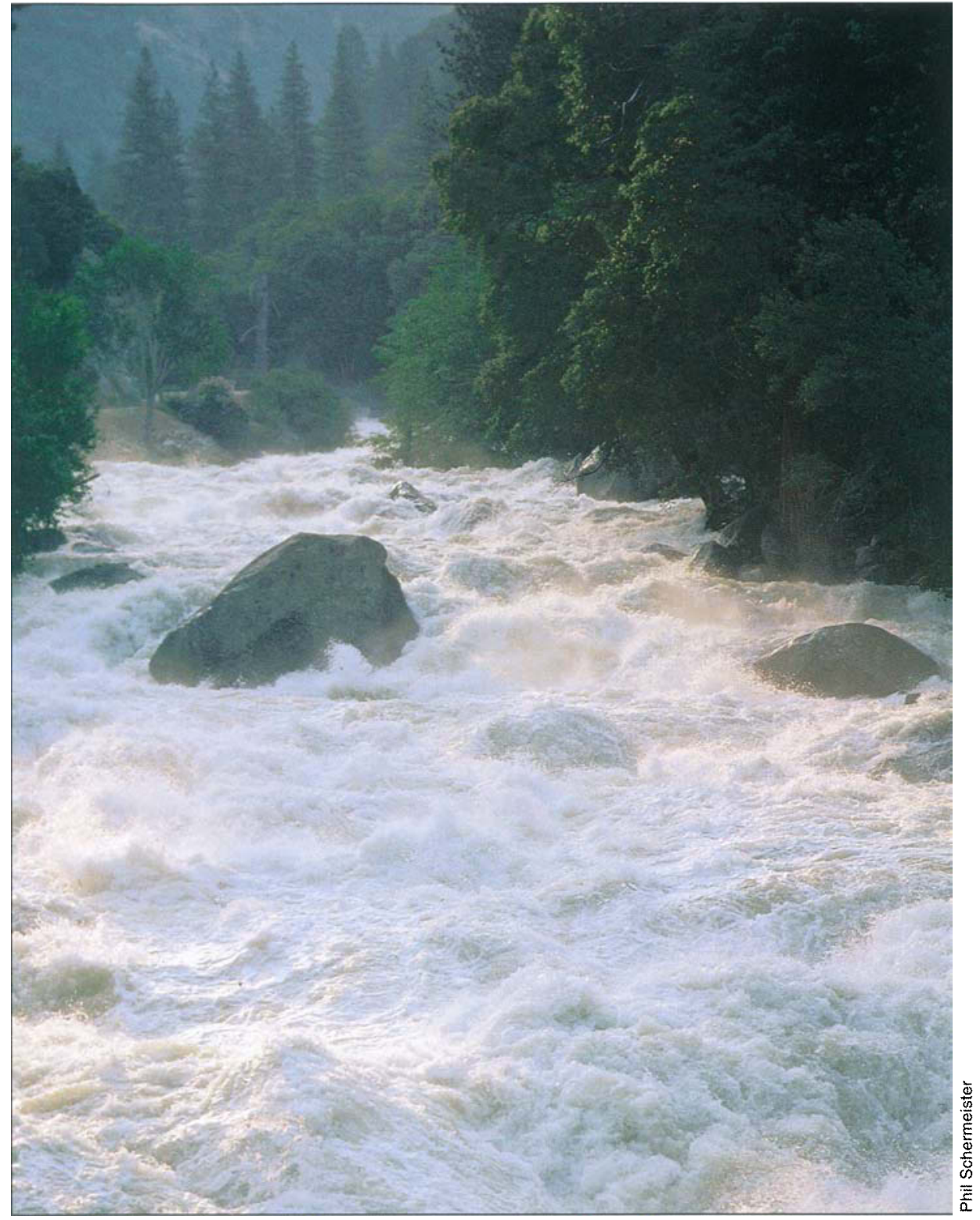

For the past century, California municipalities, farmers and environmentalists have been engaged in an epic struggle over water. As our population grows the state may be facing its greatest freshwater crisis ever.

\title{
Providing reliable supply of safe drinking water poses challenges
}

\author{
Jeannie L. Darby 」 George Tchobanoglous
}

Tn the United States, practically all Itap water from surface-water sources is chlorinated and waterborne disease epidemics among the general population are nightmares of the past. This was not the case 100 years ago when an Oregon State University scientist reportedly injected a guinea pig with water from the public supply in an attempt to provide evidence that the then raging typhoid epidemic was caused by the water (EWEB 2000). The guinea pig died, as did thousands of humans in the United States in the early 1900 s from waterborne diseases.
The pioneering work of Koch, Pasteur and others in microbiology in the mid- to late 19 th century revealed the link between epidemics and drinking water. This recognition resulted in widespread chlorination of water supplies and subsequent dramatic reductions in fatalities caused by infectious 


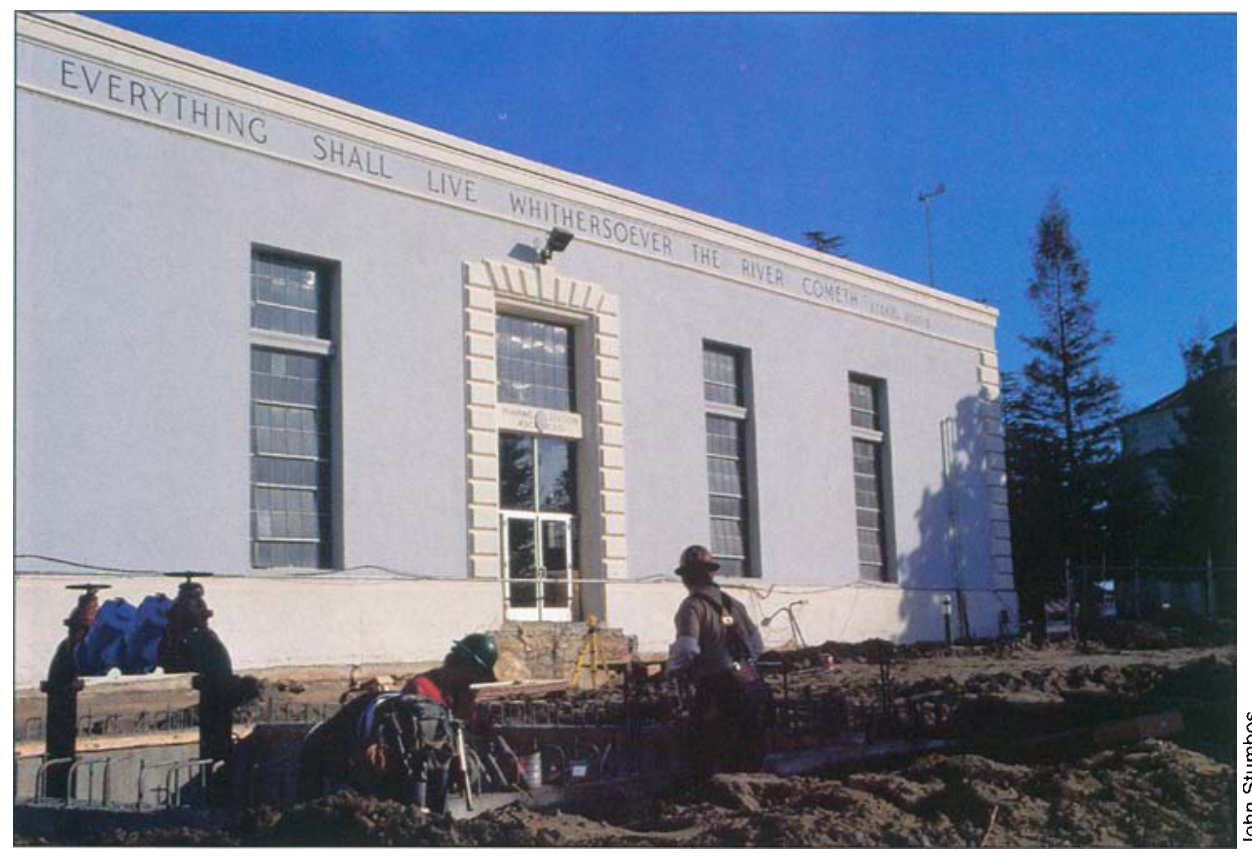

While epidemic illnesses linked to contaminated drinking water are primarily a thing of the past, in the 21 st century we are faced with new synthetic chemicals, chlorineresistant pathogens and aging distribution systems. The 75-year-old Sacramento River Water Treatment Plant, above, is undergoing major repairs.

diseases including typhoid, cholera, amoebic dysentery, bacterial gastroenteritis and giardiasis (Farland and Gibb 1993) (fig. 1).

In the 21st century, we are faced inare suspected human carcinogens, chlorine-resistant pathogens attacking the immune-deficient population, hundreds of new synthetic chemicals in the water cycle, a multitude of overstressed, small water-supply systems stead with chlorinated byproducts that

struggling to maintain water quality, and aging water-distribution systems prone to contamination.

At the same time, there has been much publicized debate in California about the tug-of-war among municipalities, agricultural interests and environmental concerns over water use. Municipalities want a reliable, economical, safe and palatable source of tap water to support growing populations and development. Agricultural interests seek an abundant supply of fresh water to irrigate a system that produces a majority of the U.S. food supply. Environmental concerns include providing enough water of sufficient quality to protect or restore aquatic life in California's rivers, lakes and estuaries.

Indeed, California and the world - are facing perhaps the greatest freshwater crisis in history (Leslie 2000; Conniff 1993). The evolution of drinkingwater regulations and issues related to water qual-

Fig. 1. Evidence of impact of chlorination on U.S. public health. Crude death rate for infectious diseases in the United States, 1900-1996. Source: Armstrong et al. 1999.
Producing an everincreasing quality of water at a centralized facility and then transporting it through aged, corroding pipes caked with scale and bacteria is not sustainable.

\section{Drinking-water regulations}

In 1914, the first federal regulation of drinking water was instituted with a standard for coliform bacteria, administered by the U.S. Public Health Service (US PHS), and applied only to water systems serving interstate common carriers (e.g., railroads and vessels). Over the next 50 years, the standards were revised to include maximum limits for inorganic substances with identified acute or chronic adverse health effects and radioactivity, as well as guidelines on source-water protection. The regulations only applied to interstate drinking-water systems, although many states, such as California, patterned their early regulations after the US PHS (fig. 2).

In the 1960s, as the mobility of the U.S. public increased, so did their expectations for consistently highquality drinking water. These demands, coupled with highly variable and sometimes ineffective state regulations, resulted in the passage of the federal Safe Drinking Water Act (SDWA, PL 93-523) in 1974. With this act, Congress authorized uniform national drinking-water regulations that were applicable to all public water systems. Under the SDWA, the U.S. Environmental Protection Agency (US EPA) was given the responsibility to establish and oversee national drinking-water regulations. State governments were granted the primary responsibility (primacy) for implementing and enforcing SDWA provisions if they adopted and enforced regulations no less stringent than the national drinking-water regulations, with the option to establish more stringent regulations. 
The Central Valley and State Water projects have been called the greatest system for moving water in history. On the California Aqueduct, the Harvey O. Banks Pumping Plant helps to transport water from the north, where $75 \%$ of the state's precipitation falls, to the south, where most of its population resides.

After passage of the federal SDWA, California adopted its own Safe Drinking Water Act (Health \& Safety Code, Chap. 7, Stat. 1976, c. 1087) and established primacy; it has maintained drinking-water regulations at least as stringent as those established under the federal SDWA and, in some cases, slightly more stringent.

In response to public concern over the slow promulgation of regulations, amendments to the federal SDWA in 1986 (PL 99-339) mandated the establishment of new regulations according to specific timetables. Since that time, the US EPA has continually promulgated new regulations for contaminants identified in the water cycle including synthetic organic and inorganic compounds, radionuclides and disinfection byproducts, as well as establishing rules for disinfection and filtration and maintaining a drinkingwater priority list of contaminants. With the increased pace and complexity of the regulatory setting, states with primacy must continuously update and adopt the new federal regulations. At the same time, public water systems, typically designed and constructed for a 20-to-30-year horizon, must predict the future or find themselves obsolete (see sidebar, p. 72).

\section{Water quantity considerations}

California's ability to provide an adequate quantity of water to all users has always been dictated by weather, demographics and conflicting needs. Cycles of severe drought and flood are inevitable. Moreover, $75 \%$ of the state's precipitation falls in the north, where only $25 \%$ of the population resides, and much of the precipitation occurs in the winter and early spring. These factors were the principal driving forces behind the development of the federal Central Valley Project begun in the 1930s and the State Water Project of the 1960s. These combined

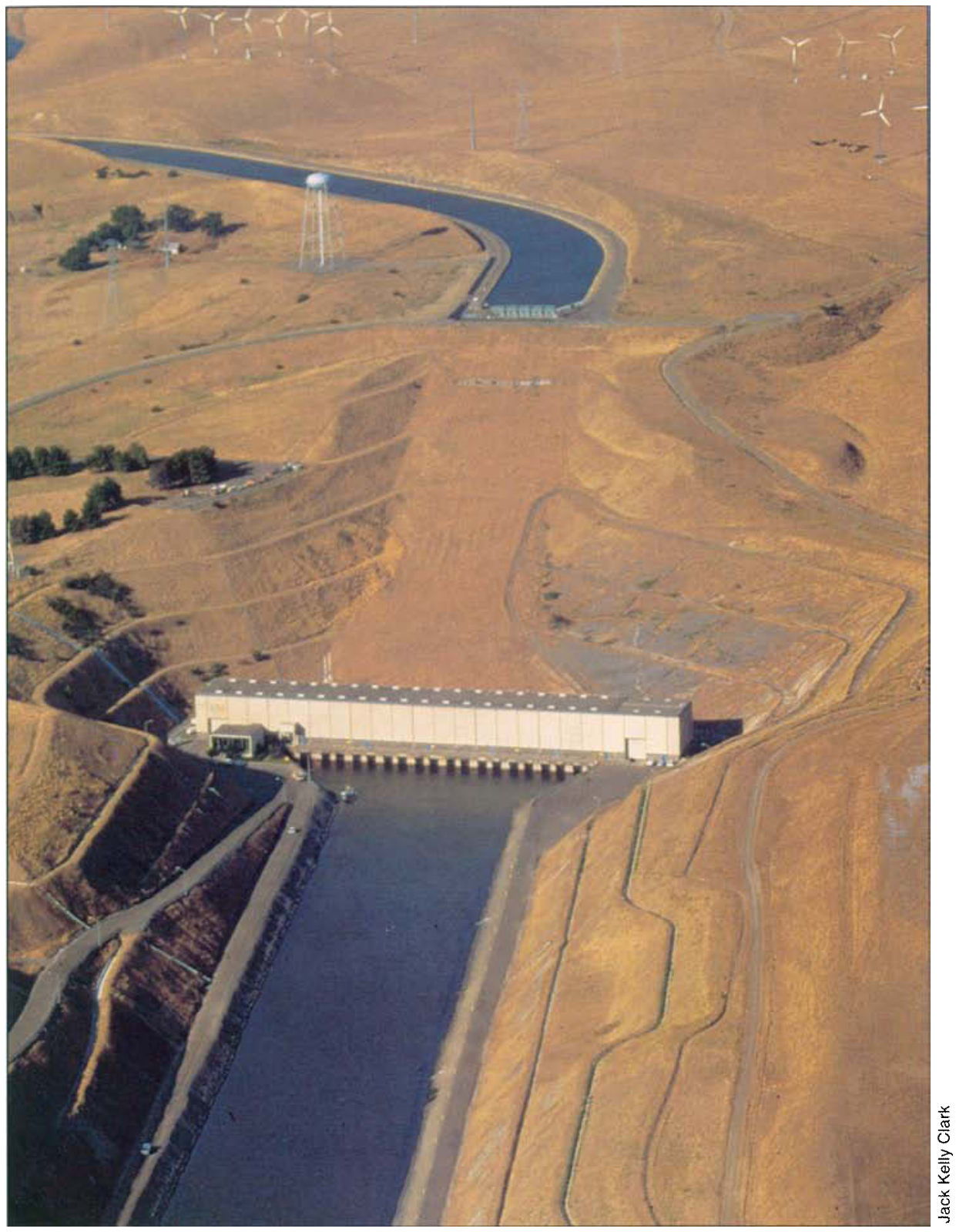

Chlorination of sewage to protect New York City drinking water

$$
\begin{aligned}
& \text { Chlorination of drinking water to } \\
& \text { stop typhoid epidemic in Chicago } \\
& \text { California legislates control of } \\
& \text { public drinking water }
\end{aligned}
$$
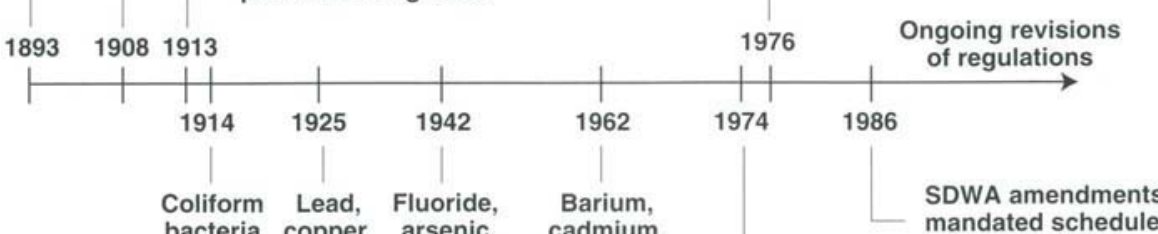

$$
\begin{gathered}
\text { U.S. PHS regulates interstate } \\
\text { drinking waters }
\end{gathered}
$$

mandated schedule for new regulations

SDWA*, uniform national drinking-water regulations

Fig. 2. Timeline of development of drinking-water regulations.

*Safe Drinking Water Act 


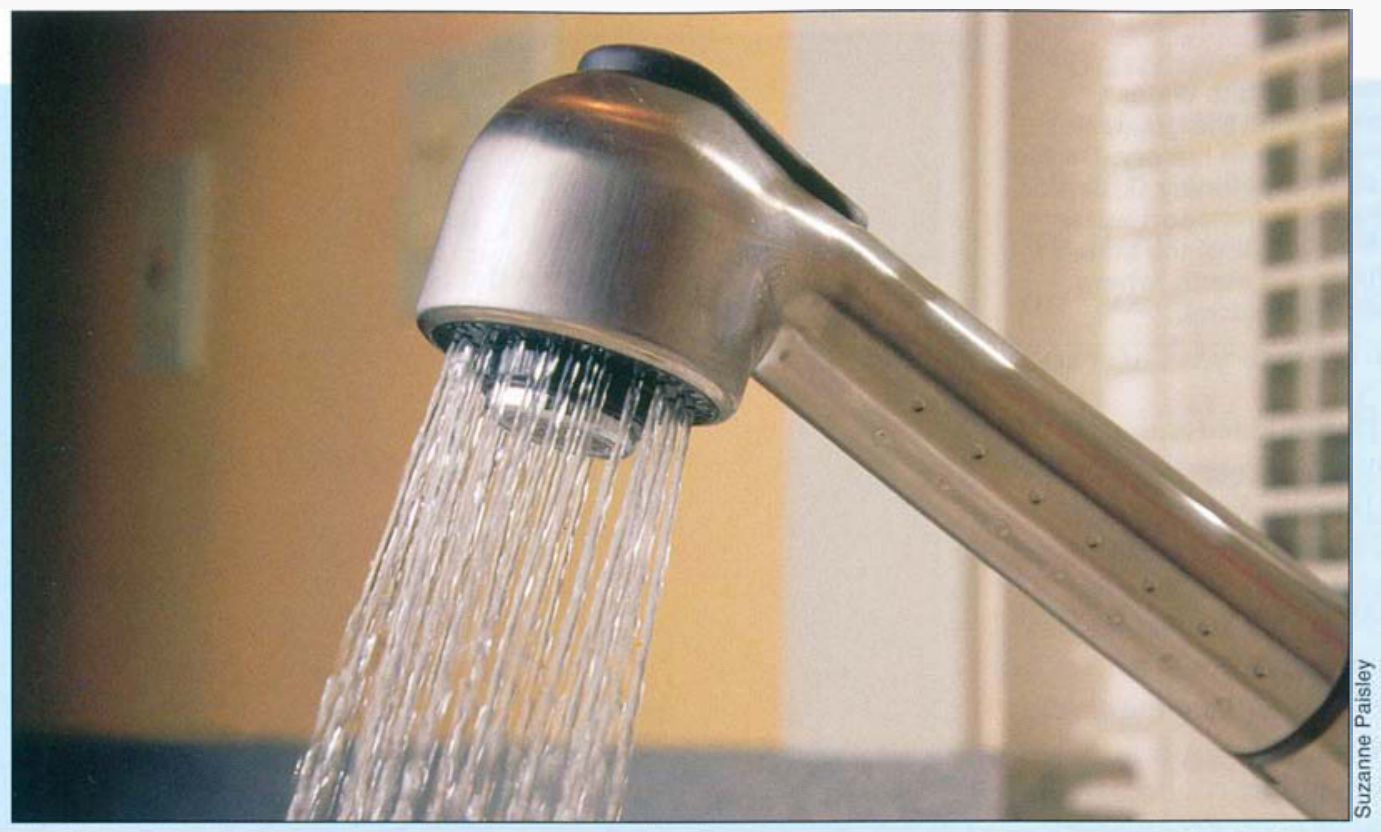

\section{From surface water and groundwater to the tap}

The primary objective of tap-water treatment is to prevent pathogenic organisms, particulate and dissolved matter, and other contaminants that pose a health threat or adversely affect water aesthetics (e.g., color, odor or taste) from reaching the consumer. Conventional treatment of tap water from surface sources entails (fig. 1):

- coagulation - adding a chemical to make suspended particles "sticky";

- flocculation - slow mixing to promote particle collisions so that small particles aggregate to form larger particles;

- sedimentation - gravity settling of the aggregated particles;

- sand filtration - removing fine particles remaining after settling;

- sometimes, carbon filtration adsorbing dissolved contaminants; and

- chlorine disinfection.

Groundwater supplies, on the other hand, are often used by municipalities with minimal (e.g., chlorination at the

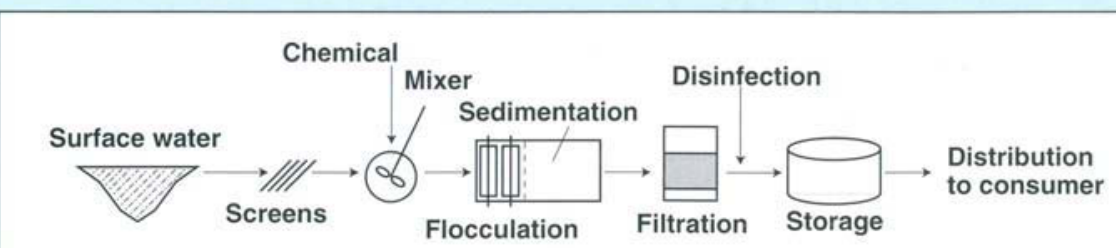

Fig. 1. Surface-water treatment.

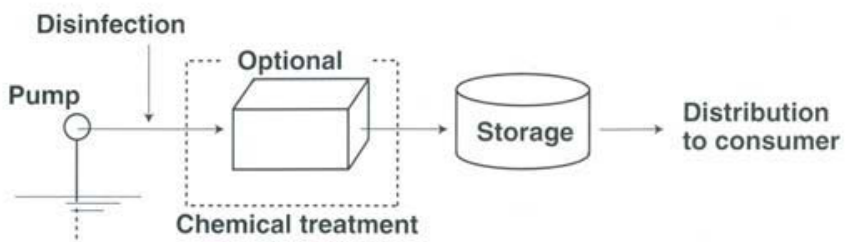

Fig. 2. Groundwater treatment. wellhead) or no treatment (fig. 2). Some very hard groundwaters containing excess calcium and magnesium may require chemical treatment on a large scale (e.g., precipitation) or home treatment (e.g., softening) to avoid the deposition of those minerals in household heaters and surfaces, and to improve soap use.

The tap-water industry uses a multiple-barrier concept to protect public health. Multiple barriers include selecting and protecting the best possible source water; removing contaminants with physical and chemical processes and disinfection; testing the final product water; and maintaining a residual disinfectant in the water to guard against regrowth or re-entry of microorganisms during storage and distribution.

After treatment, the water enters a distribution system and is supplied to the consumer upon demand from the tap. Distribution systems for public water systems usually consist of a network of water mains, valves, auxiliary pumping, chlorination substations, storage reservoirs (e.g., underground storage basins, ground-level reservoirs and elevated storage tanks) and service lines.

$$
\text { - J.L.D. and G.T. }
$$


projects have been called the greatest system for storing, controlling and transporting water the world has ever known (Conniff 1993) and have allowed for unparalleled agricultural, municipal and economic development. But they have also been criticized as destroying fragile ecosystems and creating a nonsustainable irrigationbased economy.

On the demand side, Californians exert a municipal demand for treated tap water of between 65 and 300 gallons per capita per day (gpcd), depending on geographic location, type and economic status of community, water pressure, cost, water system management and perceived need for conservation. By the year 2025, the projected population of 48 million will demand between 1 trillion and 5 trillion gallons per year. Captured runoff from annual precipitation currently supplies about 3 trillion gallons per year shared between municipalities and focused environmental concerns (fig. 3).

Municipal demands clearly will exceed the currently available supply of surface water, even without considering the impacts of unpredictable but inevitable droughts. In many locations in California, the locally available supply has already exceeded demand, and has impacted development decisions. Increased use of the relatively vast

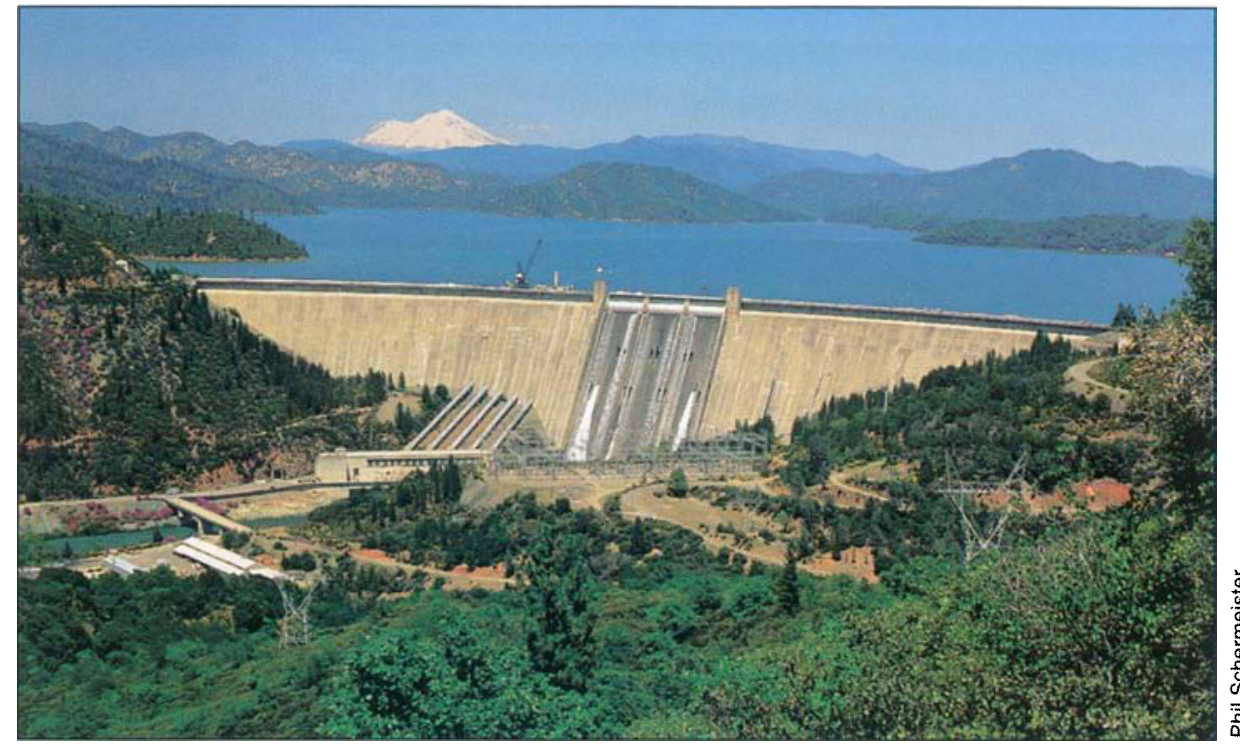

Just one-fifth of California's precipitation is captured in the state's reservoir system, which includes Shasta Dam near Redding; of our stored water, $75 \%$ to $80 \%$ goes to agriculture. Of the remainder, as little as $16 \%$ of water treated to conform with drinkingwater standards is destined to come into contact with humans. groundwater reserves can only go so far in meeting shortfalls before subsidence, saltwater intrusion and overpumping become intolerable. Among the much discussed remedies to the supply and demand imbalance are conservation and water reuse, importing more water from outside the state, diverting some of the water directed at agriculture to municipalities, and desalinating ocean water (Howitt 2000).

\section{Water quality considerations}

California's ability to continue supplying tap water of acceptable drinking-

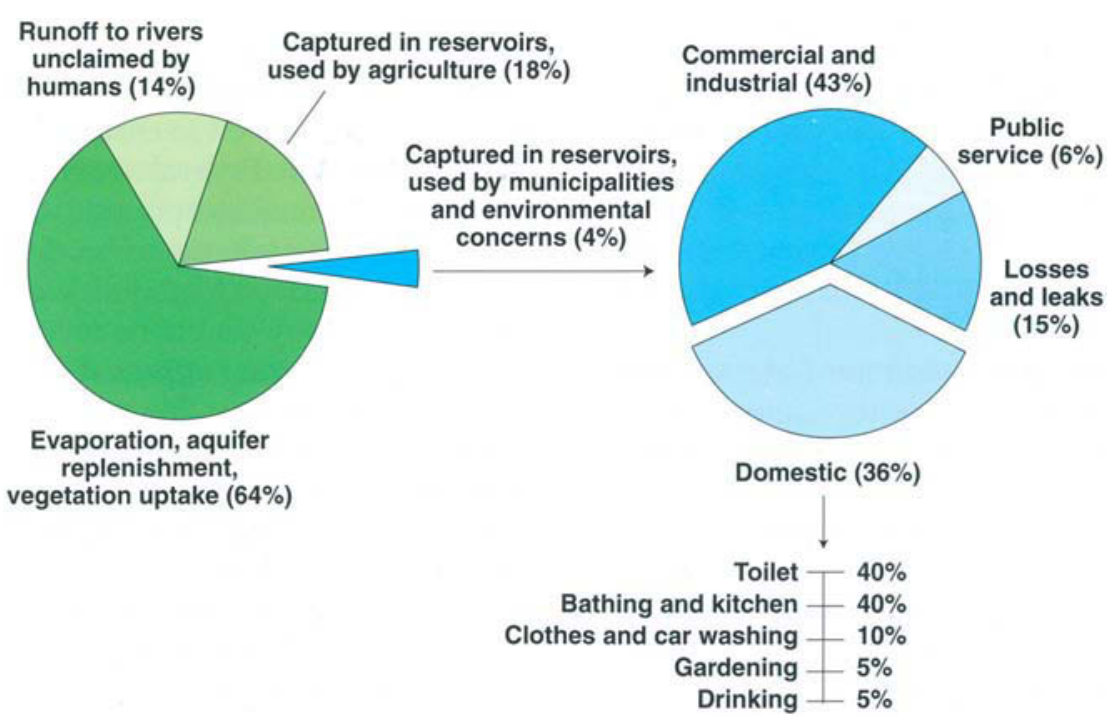

Fig. 3. Fate of the 63 trillion gallons of precipitation falling in California per year, on average. Sources: Conniff 1993; Tchobanoglous and Schroeder 1987. water quality is impacted by the existing infrastructure for treatment, distribution, use and discharge of tap water as well as the emergence of new categories of chemicals and microorganisms. Of the 63 trillion gallons of precipitation that falls in California each year, about one-fifth is captured and stored in the mammoth system of reservoirs and is transported throughout the state. Approximately $80 \%$ of that captured precipitation is untreated and used for agriculture, leaving the remainder for municipal and focused environmental uses (Conniff 1993; Tchobanoglous and Schroeder 1987) (fig. 3).

As little as $16 \%$ (i.e., $45 \%$ of the $36 \%$ associated with domestic use) of the water treated and conforming to drinking-water health standards in municipalities across the state is actually likely to come into direct contact with humans, principally by bathing and drinking. The quality of water destined for toilet flushing, firefighting and industrial use is indistinguishable from that destined for drinking.

After usage, all tap water is typically recombined and sent via gravity sewers to a central wastewatertreatment plant, where it is treated and discharged back into the environment. Water that has been minimally contaminated (e.g., via showering) is recombined with water that has been contaminated with human and indus- 


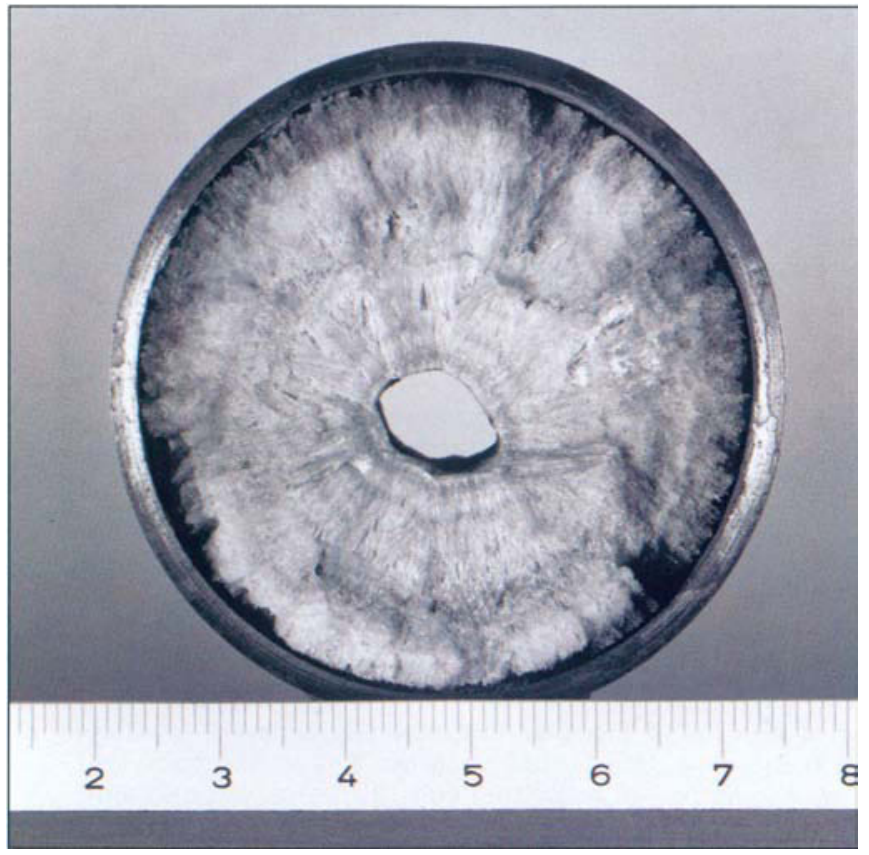

Fig. 4. Scale buildup in water-distribution pipe. Improper management of water quality in distribution systems has led to the formation of internal scale and the subsequent reduction in water-carrying capacity. Scaled surfaces are also more susceptible to growth of biofilms.

trial wastes. With hundreds of thousands of leaky sewers crisscrossing California, anything found in wastewater will appear eventually in drinking-water supplies.

\section{Distribution lines need repair}

The challenge of sustaining a reliable quantity of water free of chemical and microbial contamination for human use is made more difficult by the current status of tap-water distribution lines in the state. Many of the existing distribution systems are plagued with internal scaling and the growth of biofilms, and are susceptible to leaks and breaks (fig. 4). Biofilms are layers of microorganisms that attach themselves to surfaces and grow. The organisms are often chlorine-resistant and are possible conveyors of disease. Pipe deterioration can also result in the loss of significant quantities of water. Unaccounted water losses in distribution systems are typically $10 \%$ to $20 \%$, but losses as high as $40 \%$ have been reported.

More waterborne outbreaks are due to distribution-system deficiencies than are due to treatment deficiencies. Any system with a long distribution line, which is the norm in drinkingwater systems, is going to require a disinfectant residual (currently a chlorinated compound), which automatically lim its the quality of the water that can be delivered to the consumer.

\section{Future in focus: Status quo is unsustainable}

How drinking water will be handled in California in 2025 is unknown, but the status quo is not sustainable. In addition to the challenges posed by an increasing and industrialized population, the state will have to continue to deal with cycles of drought and flood, as well as periodic earthquakes and forest fires, events that have harried Californians throughout history. California has always led the nation in tackling tough water-resources problems. Meeting the challenge of assuring a reliable and safe supply of tap water provides opportunities to continue this leadership. Eight predictions and/or suggestions for the future follow.

Refocus regulations. Producing an ever-increasing quality of water at a centralized facility and then transporting it through aged, corroding pipes caked with scale and bacteria is not sustainable. The focus of future regulations is expected to shift from quality of the water exiting the treatment facility to the quality of the water at the user's tap.

Better management of new compounds. Our country's unbridled manufacturing of new compounds must be tempered with the need to develop, use and discharge only those compounds that have been proven to be either environmentally benign or can be removed from water supplies by available technology.

In the coming decades, it is clear that sources for drinking water will be exposed to a greater variety and an in- creased load of compounds that watertreatment plants were not designed to handle. Removal of conventional constituents such as chlorine-vulnerable bacteria and turbidity (very fine particles) were the basis of early drinkingwater regulations and treatment-plant design. Chemical treatment followed by sand filtration and disinfection were adequate. In the decades following World War II, attention was expanded to anthropogenic organic compounds, designated as priority pollutants, which required upgrading treatment plants with new technology such as granular activated-carbon filters and membrane filtration. For the most part, these new compounds could be removed adequately.

However, in recent years, several new classes of compounds have arisen including veterinary and human antibiotics, prescription and over-thecounter drugs, industrial and household products, and sex and steroidal hormones including endocrine disruptors. Many of these compounds may be finding their way into drinkingwater supplies because existing water and wastewater-treatment technology is not readily available to handle the increasingly diverse load of compounds.

Little is known about the possible environmental and health effects of these newer compounds. Perhaps we need to regulate the production and discharge of new compounds into the environment with the same degree of care as we regulate new medical drugs before they are allowed to enter the human population. Federal oversight of the testing of new compounds to certify either a benign impact on the water cycle or proven treatability with existing technology should be required before granting approval for production and use.

\section{New and chlorine-resistant} pathogens. In addition to the changing nature of chemical contamination of waters, improved knowledge will lead to a growing concern about pathogens in the water supply. These may include opportunistic pathogens such as Pseudomonas auruginosa, Acinetobacter, Mycobacterium, Flavobacterium, Legionella and fecal Klebsiella 
that affect select populations at risk including the elderly, infants and immunocompromised individuals. Concern will also continue to be focused on chlorine-resistant pathogenic protozoa such as Giardia lamblia and Cryptosporidium parvum (see sidebar, p. 78).

When drinking water was first regulated, the focus was on coliform bacteria - microorganisms that colonize the intestines of warm-blooded animals, including humans, and are shed in feces. It was reasoned in the early 20th century that water could not become polluted with human fecal matter without this organism being present. Today, it is recognized that the absence of coliform bacteria is not a reliable indicator of the absence of a microbial threat. However, our capability of monitoring for the legions of waterborne viruses, bacteria and protozoa potentially in drinking water is severely constrained by both economics and technology. Some of the identified pathogens can be tested for at great cost, many times more than the cost of testing for coliform bacteria. For others, reliable detection methods have not yet been developed. Still other organisms have yet to even be identified by name.

In past decades, federal funding for investigating microbial contaminants of drinking water was significantly less than the amount spent on chemical contaminants. This funding shortfall must be rectified if progress is to be made in ensuring the high quality of drinking water.

Assistance for small watersupply systems. The impossible burden faced by small public-water systems attempting to meet current regulatory requirements and prepare for likely future increases in chemical and microbial contamination of water supplies must be recognized, and adequate funding must be made available.

There are nearly 10,000 small water systems in California that serve only $2.5 \%$ of the population. There are another 1,200 large systems (with 200 service connections or more) that serve $97 \%$ of the population (Allen and Darby 1994). The large systems have

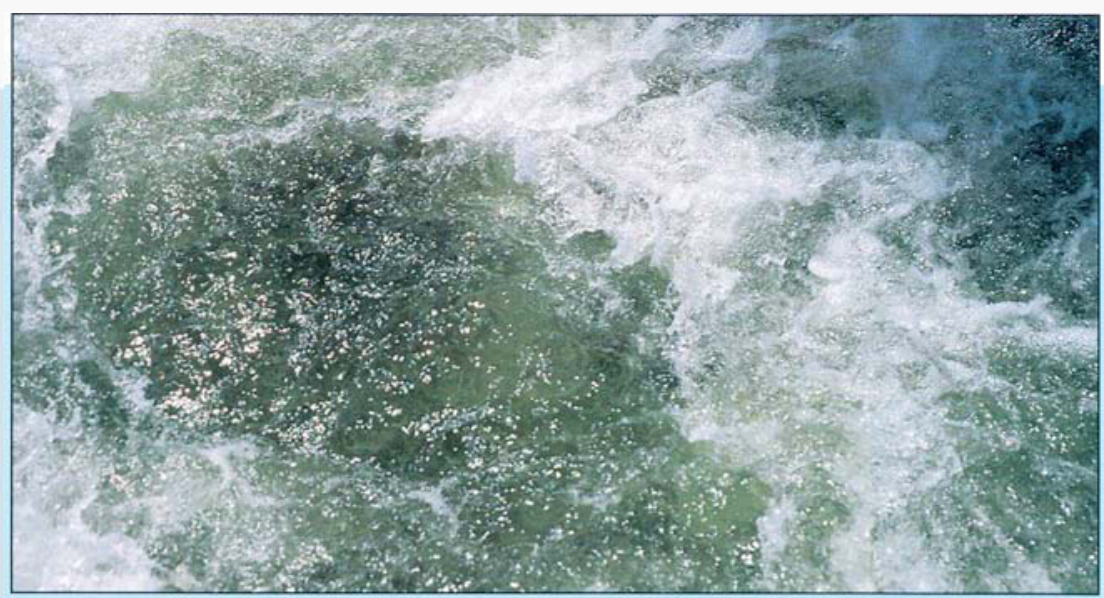

\section{Are bottled water and point-of-use devices a panacea?}

$\mathrm{C}$ onsumption of bottled and vended water in the United States is increasing annually by about $10 \%$ and is highest in California, where residents consume more than one-third of the bottled water sold nationwide (Allen and Darby 1994). Thirty-three percent of Californians use bottled water as their primary source of drinking water (The Field Institute 1990). The average cost of bottled water in the United States is approximately $\$ 3.40$ per gallon, more than 2,500 times the price of tap water (International Bottled Water Institute 2000). In California, approximately 100 facilities produce bottled water, and 30 out-of-state and 11 international producers market water here, according to the California Department of Health Services, Food and Drug Branch (FDB). Approximately $70 \%$ of the source water for the bottled-water industry is from groundwater, with the remaining produced from tap water.

Treatment of bottled water spans a wide range of options. A spring water may undergo only filtration and ozonation to produce a "natural spring" water, whereas a chlorinated tap water may be subject to activated-carbon filtration, reverse osmosis or deionization, and ozonation to produce a "purified" water. Bottled water is mostly treated to improve aesthetics such as appearance.

The bottled- and vended-water industry is regulated to a much greater degree in California than much of the United States. California's Sherman Food, Drug and Cosmetic Law is the basic statute that authorizes such regulation. FDB is the primary oversight agency for the bottled- and vended-water industry, regulating all products sold here. Although there are taste differences among the various bottled and tap waters, there is no basis for believing bottled water is safer than tap water in compliance with state waterquality standards (Allen and Darby 1994).

Point-of-use treatment devices usually consist of an under-thesink carbon and/or membrane filter intended to remove objectionable particulate and dissolved constituents from the tap water. In the best of situations, the devices function as desired. However, if not designed, manufactured and tested according to certification and performance standards, these devices may simply be a waste of money. Moreover, if not properly maintained, particularly in terms of changing the cartridges as specified, the devices can actually contribute microorganisms to the water. - J.L.D. and G.T. 


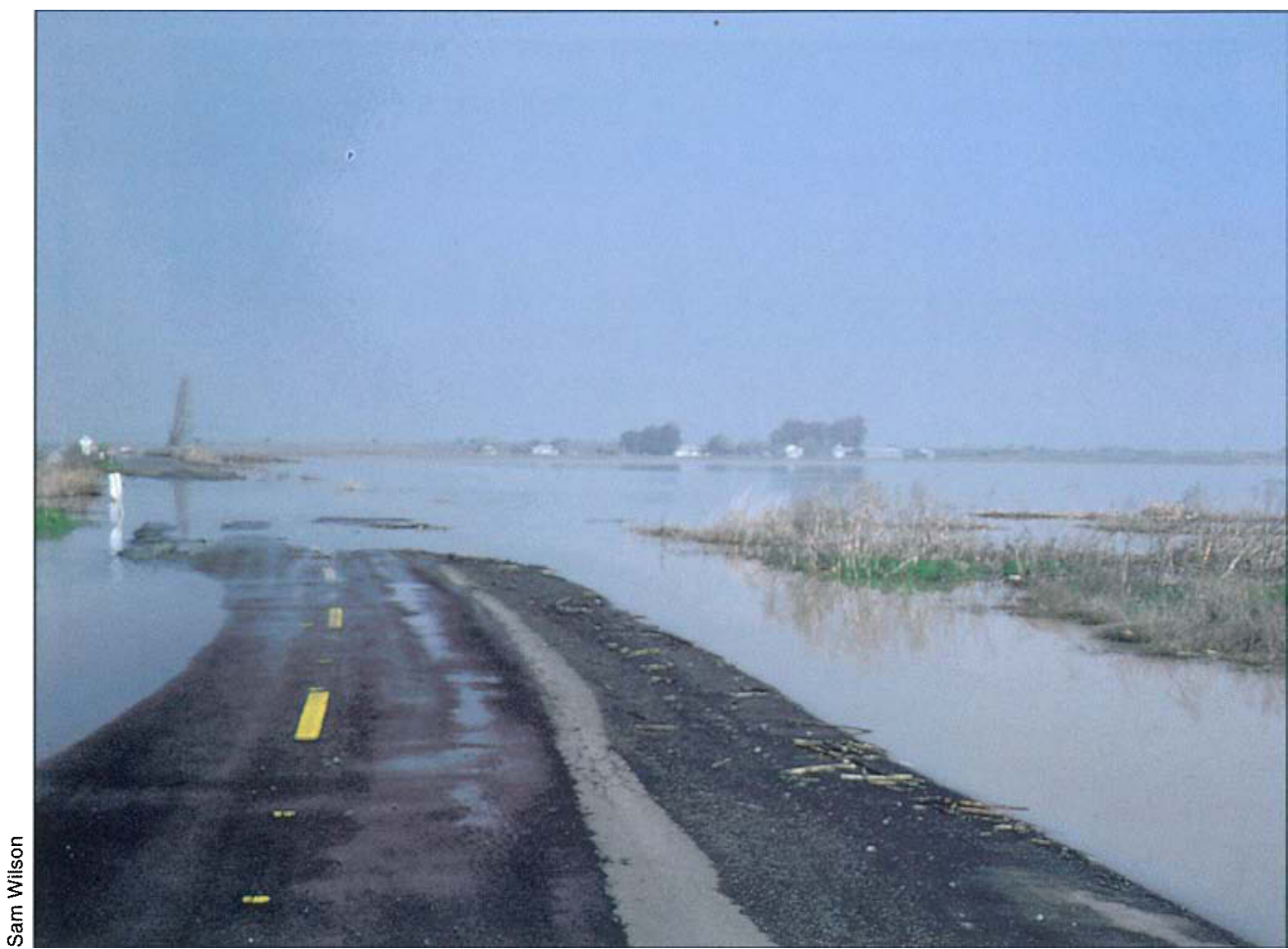

Droughts and floods, such as this 1986 event in the San Francisco Bay-Delta, are inevitable. New strategies are needed to manage precious water resources, such as truer pricing systems for tap water, water recycling and reuse, dual distribution systems for drinking water and water intended for other purposes, and more effective regulation of water contaminants.

access to financial resources and technical and managerial expertise that are unavailable to small systems. The overwhelming majority of violations of drinking-water regulations are attributed to the smaller systems. Complicating the situation is the fact that the majority of tap water comes from large surface-water treatment plants, but the majority of tap-water systems are served by groundwater, which is susceptible to undetected but sometimes widespread contamination by chemicals. No matter what the future holds, adequate treatment and regulation of these small systems will become more difficult, but must be addressed by society as a whole.

Alternative approaches for existing developments. Point-of-use devices (such as under-the-sink activatedcarbon and/or membrane filters or ultraviolet (UV)-light disinfection units) and bottled water are likely to become increasingly popular. However, bottled water and point-of-use devices in California - as currently produced, regulated and marketed are not reliable alternatives to the available public water supply (see sidebar p. 75). In certain cases, tap wa- ter may be deemed unacceptable for various reasons, such as chemical contamination of the source that is not amenable to available centralized treatment technology; microbiological contamination via deteriorating distribution lines; or need to serve a vulnerable subpopulation. In these cases, it may be cost-effective for the public utility to provide and manage the distribution of sterilized bottled water and/or placement and maintenance of point-of-use devices.

Alternatively, small, packaged treatment plants (i.e., a bank of membrane filters followed by UV-light disinfection) may be located in existing residential, commercial and industrial developments on a decentralized basis and managed by the centralized water utility to provide the extra level of treatment necessary.

New housing paradigm. In the future, new housing developments will be severely limited by the lack of available water. As a result, developers will be responsible for financing the construction and maintenance of water-treatment facilities. These new facilities - using advanced technologies including ultrafiltration and UV- light disinfection - will likely be built on the development sites, enabling the use of short distribution lines, and will be managed by a centralized facility such as the existing municipal watertreatment plant.

Water quantity restrictions will likely provide incentives for new developments to include dual waterdistribution systems, whereby water destined for consumption or human contact would be separate from that destined for other domestic uses and firefighting. As water quality standards tighten, the absurdity of treating water destined for toilet flushing the same as water destined for human consumption will become increasingly apparent. Incentives should also be established to design landscaping with low water requirements and to drive the reuse of water on site to reduce the costs of wastewater treatment.

\section{Integrate management of drink-} ing and wastewater. Currently tapand wastewater treatment and regulatory entities are distinct and, for the most part, common goals and management have not been reached. One common goal is increased on-site reuse of tap water to decrease the need for both tap-and wastewater treatment and to minimize contamination of the water supply. Another common goal could be to influence manufacturers to develop products that are benign to the environment or that can be treated effectively. Creating a sustainable future while meeting California's diverse water needs will require an integrated, comprehensive approach.

\section{Proper pricing for valuable} resource. Predicting the future costs of tap water and how the public will respond in terms of changes in usage is at best an exercise in guesswork. Current costs for tap water vary depending on size, ownership and complexity of the system, but are generally quite inexpensive.

In the United States, the cost of tap water ranges from $\$ 0.45$ to $\$ 13.55$ per 1,000 gallons, with an average cost of $\$ 1.30$ per 1,000 gallons; in California, costs range from $\$ 0.45$ to $\$ 2.85$ per 1,000 gallons, with an average cost of $\$ 1.60$ per 1,000 gallons, according to the American Water Works Associa- 


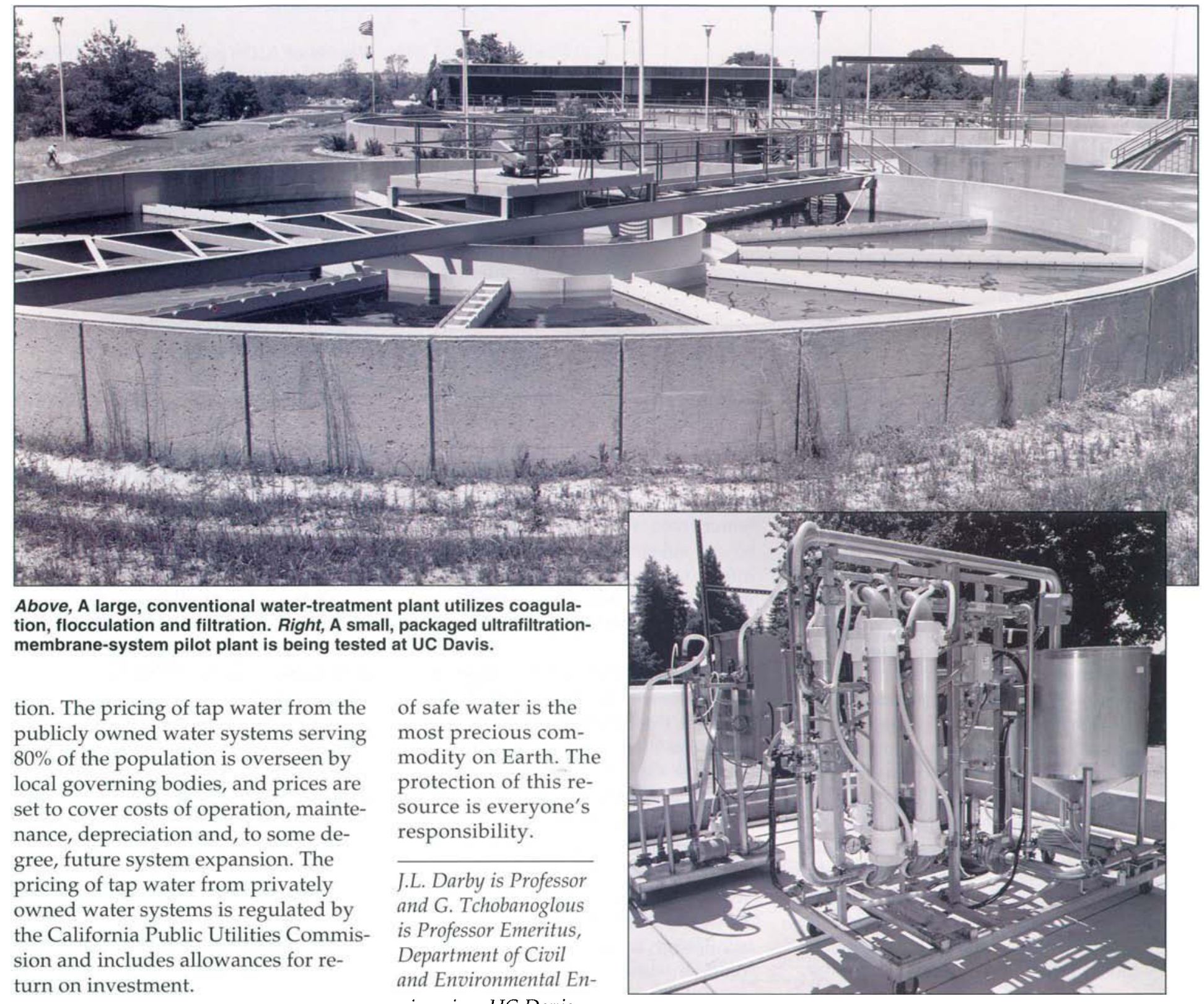

Over the next 25 years, the price of tap water will (and should) rise in response to required maintenance of deteriorating distribution lines, use of more advanced and expensive treatment technologies to remove the increased and diverse chemical load in water sources, increased attention placed on opportunistic pathogens, and shortfalls in quantity. Subsidies may be required to offset the cost for low-income individuals. It may well be that price increases will provide economic incentives to decrease water usage, spur the invention of commercial products to conserve water, and promote appropriate landscaping for a desert climate. Ultimately, we all must recognize that a reliable supply gineering, UC Davis.

The invaluable assis-

tance of students Nicole Giese and Vikram Chowdary in preparing this article is much appreciated by the authors.

\section{References}

Allen L, Darby J. 1994. Quality control of bottled and vended water in California: A review and comparison to tap water. J Environ Health 56 (8): 17-22.

Armstrong GL, Conn LA, Pinner RW. 1999. Trends in infectious disease mortality in the United States during the 20th century. JAMA 281:61-6.

Conniff R. 1993. California: Desert in disguise. National Geographic, special edition (November):38-52.

[EWEB] Eugene Water and Electric Board. 2000. Turn-of-the-century typhoid epidemic spurs public utility. www.eweb.org/ about/history/typhoid.html. Accessed September 2000.

Farland W, Gibb H. 1993. U.S. perspective on balancing chemical and microbial risks of disinfection. In: Craun GG (ed.). Safety of Water Disinfection. Washington, DC: $|O S|$ Press. p 3-10.

Howitt RE. 2000. Is California's future hydraulically sustainable? Cal Ag 54(2)10-5.

International Bottled Water Institute. 2000. www.bottledwaterweb.com.

Leslie J. 2000. Running dry: What happens when the world no longer has enough freshwater? Harper's Magazine (July):37-52.

Tchobanoglous G, Schroeder E. 1987.

Water Quality. Reading, MA: Addison-Wesley Publishing Co. $768 \mathrm{p}$.

The Field Institute. 1990. Californians views on water: A survey of Californians opinions about issues of water supply, development, quality and policy. San Francisco. p 13-28. 